\title{
(Re)Constructing and Resisting Irregularity: (Non)citizenship, Canada's Interim Federal Health Program, and Access to Healthcare
}

\author{
LAURA CONNOY \\ Western University, Canada
}

\begin{abstract}
This article analyzes the experiences of refugee claimants in Toronto's everyday healthcare places, like walk-in clinics, doctor's offices, and hospitals, in the aftermath of the 2012 Interim Federal Health Program (IFHP) revisions. By drawing upon critical migration scholarship that prioritizes (non)citizenship, as well as semi-structured interviews, I highlight how the social positioning of refugee claimants is modulated in ways that justify and extend the IFHP revisions to effectively deny access to healthcare, demonstrating the indeterminacy of access. I understand this process through the concept of irregularity, a non-juridical status that is contingently configured and enforced by state and non-state actors when one is (re)constructed as "out of place," hence limiting access to resources and rights. In accordance with citizenship, it indicates how we can think of the (re)fashioning of people and groups particularly within the everyday. I follow this with a critical analysis of the contestations that emerged to challenge the IFHP revisions and the irregularity of refugee claimants so as to capture the politics of irregularity.
\end{abstract}

KEYWORDS refugee claimants; (non)citizenship; irregularization; healthcare; Interim Federal Health Program

Over the past decade, Canadians have witnessed the introduction of measures that aim to circumvent the rights of refugee claimants. Most notably, in 2012, the Conservative federal government amended Canada's existing refugee legislation with the introduction of the Protecting Canada's Immigration System Act (PCISA). With the aim to protect Canada and its citizens from "bogus" refugee claimants, the PCISA created specific categories of migrants and refugees, emphasized efficiency of the system, and expanded powers to the government (Atak, Hudson \& Nakache, 2017; Huot, Bobadilla, Bailliard \& Rudman, 2015). During this time, the federal government depicted Canada's social assistance programs and 
public services, like healthcare, as key "pull factors" and vulnerable to exploitation by refugee claimants unless control measures were introduced (Huot et al., 2015, p. 135). An ensuing measure was the June 2012 revocation and replacement of the Interim Federal Health Program (IFHP), a federal healthcare coverage program for refugee populations.

Introduced in 1957, the IFHP covers basic and supplementary services, and prescription medications for refugee populations and other vulnerable groups. The 2012 replacement program significantly reduced coverage for basic and supplementary services and denied coverage for prescription medications for refugee claimants. While some of the reasons for the move were to ensure "fairness" to Canadians, "protect public health and public safety in Canada," and "defend the integrity of Canada's refugee determination system and deter its abuse," critics claimed the cuts were intended to deter individuals from making an asylum claim and to force those already in the country to leave more quickly (Canadian Doctors for Refugee Care, et al. v. Canada, 2014, pp. 7-8,18).

As precarious status noncitizens, ${ }^{1}$ it is unsurprising that refugee claimants face barriers to rights and resources, including healthcare. Although the provision of healthcare to refugee populations is federally mandated, the (non)citizenship and anti-refugee discourses employed by the federal government during the time of the 2012 changes problematized this custom (along with those who receive IFHP coverage) to justify their abdication as providers of healthcare coverage to refugee claimants. The targeting of refugee claimants was not only witnessed at a federal level. Healthcare professionals also came to target this population within everyday healthcare places (like walk-in clinics, hospitals, and doctor's offices) as a result of such discourses and confusion regarding the details of the IFHP, which led to unexpected denials to basic primary healthcare services regardless of IFHP coverage (Barnes, 2013, p. 6).

Drawing upon critical citizenship and migration scholarship (Baines \& Sharma, 2002; Castañeda, 2013; Hepworth, 2014; Isin, 2002), grey literature and interview data collected in Toronto, Ontario, I critically examine how refugee claimants were (re)constructed in ways that problematized their access to Canadian healthcare resources during the time of the IFHP cuts. Informed by Isin's (2002) work on the emergence of the citizen identity in relation to noncitizen "others," and how this identity is (re)defined and (re)constituted in everyday encounters (Hepworth, 2014), I highlight how refugee claimants are (re)constructed and (re)identified as "irregular," a social status position that reflects one's constructed abnormal and problematic presence. This not only problematizes and denies access to resources and rights but also affects life chances. This contingently configured process is an effect of (non)citizenship and shapes how others

\footnotetext{
${ }^{1}$ Precarious status noncitizens are persons with insecure status who are denied the rights associated with permanent residence and citizenship (Goldring, Berinstein \& Bernhard, 2009, pp. 240-241)
} 
are imagined and encountered as belonging or not belonging, deserving or not deserving. In this regard, this analysis critiques the legitimacy of the citizen/noncitizen divide and the nation-state, and questions the validity of the IFHP and the exclusion of refugee claimants from provincial and territorial healthcare coverage.

My interest lies not only in the regulatory aspects of (non)citizenship, but also how it is contested. I draw upon the concept of "acts of citizenship" those powerful forms of dissent that fundamentally call into question the unjust boundaries of citizenship (Isin, 2002, 2008). Rather than emphasizing the acts of noncitizens, I focus on the ways that healthcare professionals question and undermine the irregularity and broader health inequalities that constitute noncitizenship. The mobilization of healthcare workers and national health associations is one of the most distinctive and unexpected aspects of the IFHP, as well as the forms of organization they practice, including protests and demonstrations, occupations, data collection, op-eds, scholarly publications, and conference presentations (Jackson, 2018; Interviews with doctors, Toronto, 20 October 2015 and 10 November 2015). I also highlight the unintended outcomes of allied mobilization and their critical interrogation of the inequalities that define (non)citizenship. These acts came to constitute a new feature of refugee politics in Canada and effectively capture the politics of irregularity.

In light of the above, the purpose of this article is to showcase the politics of irregularity that came to define not only a part of Canada's social policy history but also the evolving nature of (non)citizenship. Focusing on the IFHP, I shed light on the dynamic (re)construction of irregularity in the everyday as it relates to (non)citizenship and refugee claimants, ${ }^{2}$ and by doing so, this article contributes to existing scholarship on the healthcare experiences of refugee claimants in Canada (Olsen, El-Bialy, Mckelvie, Rauman \& Brunger, 2016; Vanthuyne, Meloni, Ruiz-Casares, Rousseau \& Ricard-Guay, 2013), the IFHP (Barnes, 2013; Beatson, 2016; Dhand \& Diab, 2015; Sheridan \& Shankardass, 2015), and analyses of (non)citizenship within the Canadian context (Bhuyan, 2012; Landolt \& Goldring, 2015; Nyers, 2003, 2010; Villegas, 2013, 2015a, 2015b). Below, I provide an overview of my research methods, followed by a conceptual framework of irregularity informed by critical citizenship and migration scholarship. An overview of the IFHP is then presented, followed by an empirical analysis of irregularity within Toronto's healthcare places. I conclude with an empirical analysis of resistance to the IFHP and irregularity.

\footnotetext{
${ }^{2}$ It is important to note that irregularity is not simply founded on the citizenship/noncitizenship dyad since many permanent residents and citizens experience barriers to services such as government-assisted refugees, and street involved and Aboriginal populations. Irregularity can therefore alert us to other forms of differentiation and discrimination founded, for example, on race and class.
} 


\section{Methodology}

Data was collected from primary (interview data) and secondary sources (scholarly publications, Federal Court documents, and grey literature). The collection of primary data occurred between September 2015 and March 2016 in Toronto, Ontario, and included semi-structured interviews with 42 participants: five healthcare professionals, four lawyers, five settlement workers, one policy specialist, seven executive directors and program managers of refugee agencies, three provincial Ministry of Health officials, five City officials, and 12 refugee claimants. I relied on academic and grey literature, as well as a Google search, to identify key actors and organizations that work with and for refugee claimants. Participants were contacted via email and cold-calling, or through snowball sampling. With regard to contacting refugee claimants, I relied on participants who worked with this population to send out information forms with contact details. This resulted in connections with two individual refugee claimants and one focus group consisting of 10 refugee claimants. Lasting between 45 minutes to one hour, interviews allowed me to gain an understanding of the effects of the IFHP, the implications of this program for the healthcare rights of refugee claimants within everyday healthcare places, and resistance strategies. The semi-structured format of the interviews allowed participants the freedom to express their interpretations of and experiences with the program, and of refugee healthcare in general. An iterative analysis was employed whereby interview transcripts were read several times to establish conceptual links; these were triangulated between participants and relevant documents to highlight and develop emerging themes. Through this methodological approach, the consequences of policy and practice and the effects of irregularity in everyday life are revealed (Johnson, 2014, p. 206). This research was approved by the Office of Research Ethics at the University of Waterloo; all of the data collected for this project was treated according to ethical guidelines.

\section{(Non)Citizenship and Irregularity}

Citizenship is conventionally understood as a legal and political institution constituted by "a collection of rights and obligations which give individuals a formal legal identity" (Turner, 1997, p. 5, 7). This formal legal status and identity not only denotes one's inclusion (i.e., legal membership) in the nation-state but also performs an allocative function that shapes access to key (scarce) societal resources, including healthcare (Turner, 1997, p. 6, 7). Isin (2002) builds upon this understanding by drawing attention to how citizenship, as an invented and inherited phenomenon, is narrated by dominant groups who articulate their identity in relation to others - being strangers, outsiders, and aliens. 
The formation of citizens and others involves relations of power, exercised through strategies and technologies of citizenship that shape conduct, constitute citizens as virtuous, and work to legitimize the inheritance and exclusivity of citizenship (Isin, 2002). In this regard, citizenship is not a static identity, but rather one founded on alterity, in that citizenship emerges in relation to others or noncitizens and evolves with time (Isin, 2002, p. 4). Encounters are a key site in the formation of others as they entail "the presence and recognition of other groups" allowing for the realization of oneself (Isin, 2002, p. 49). Landolt and Goldring (2015) and Bhuyan (2012) analyze how access to services is informed by the (re)assembling or (dis)assembling of (non)citizenship within everyday encounters between precarious status noncitizens and social service actors. Through the medium of encounters, scholars are highlighting the contingency of (non)citizenship. For example, Hepworth (2014, p. 2) approaches (non)citizenship as an "emergent condition" that is "modulated in the everyday to constitute a range of legitimately and illegitimately present non-citizen subjects," regardless of juridical status, whereby Rygiel (2011, pp. 13-14) alerts us to how the legitimacy or illegitimacy of one's presence - or one's concrete locality within space - can be modified in and through encounters, which can interrupt access to rights. The technologies that emerge in and through the encounter aim to immobilize, segregate, incarcerate, or constrain constructed others, while simultaneously increasing solidarity among citizens (Isin, 2002, pp. 25-26, 49). For example, interrogation, intimidation and humiliation is exercised by border authorities which work to construct the identity of stranger and ultimately constrain movement (Villegas 2015b, p. 2359), highlighting the inequality of the social interactions that constitute these encounters and others like them.

Heeding the above arguments, I approach (non)citizenship as a dynamic and contingent articulation of one's identity or position, and as therefore experienced variably. It is shaped, or assembled (Landolt \& Goldring, 2015), through a confluence of various elements including actors, knowledges, discourses, and practices which confer or deny rights, entitlements, and access to services, based upon the degree to which one is (re)constructed as other or noncitizen. The outcome of this constructed positioning is understood here as irregularity.

Irregularity is a positioning that reflects one's (re)constructed abnormal, or irregular, presence. As noted by Hepworth (2014, p. 7), this positioning emerges "each time particular bodies are deemed in- or out-of-place." Irregularity, in this sense, attempts to identify an effect of encounters. But, this is not one that impacts juridical status. Rather it is a non-juridical status that is contingently configured and enforced by state and non-state actors when one is (re)constructed as "out of place," hence limiting access to social resources and rights; in accordance with citizenship, it indicates how we can think of the (re)fashioning of people and groups through the 
modulation of (non)citizenship, particularly within everyday encounters. This understanding of irregularity, made in relation to critical citizenship scholarship, speaks to McNevin's (2011, pp. 15-16) valuable assertion that abnormality is part of the history of citizenship and the production of "citizenship's outsiders."

\section{Resisting Irregularity}

To approach citizenship as entailing relations of power means it is constituted by struggles that shape the content and extent of citizenship (Isin, 2002, p. 2). As argued by Isin (2002), citizenship involves moments of "becoming political," when strangers, outsiders, and aliens enact themselves as "different from the dominant image given to them" (p. 33) by questioning "categories, classifications, and identities" (p. 4). To become political then is to call into question "the naturalness of the dominant virtues" and reveal their arbitrariness (Isin, 2002, p. 275). Here, dominant virtues refer to those entitlements and exclusions that emerge in and through citizenship; it is the irregularity accorded to noncitizens and the lack of rights that inform this positioning that are rendered arbitrary and resisted.

Analyses of becoming political are founded on acts of citizenship, being "those acts when, regardless of status and substance, subjects constitute themselves as citizens or, better still, as those to whom the right to have rights is due" (Isin \& Neilson, 2008, p. 2). Acts rupture "given orders, practices, and habitus" (Isin, 2008, p. 36) by "call[ing] the law into question and, sometimes, break[ing] it" (p. 39). Through this lens, scholars have drawn attention to how: non-status Algerian refugees in Montreal selforganized to end deportation and to regularize their status (Nyers, 2006); Eritrean refugees in Israel publicized their presence as rightful through demonstrations and the issuance of ID cards (Müller, 2016); and intergenerational migrant youth in France resisted national linguistic and ethnic ideologies through vernacular music and language (Ní Mhurchú, 2016). By shifting attention away from the actor to the act itself, or in other words by emphasizing performativity, conventional ways of identifying citizen and noncitizen subjects - typically as fixed identities based on legal status - are challenged. In effect, the idea of who counts as a political subject is critically confronted. I contribute to this scholarship by focusing on the acts that emerged through the IFHP that questioned the legitimacy of the cuts and the irregularization of refugee claimants.

The acts this article focuses on are those of Canadian healthcare professionals, which differentiates them from the examples cited above. Yet, a connection is maintained to acts of citizenship scholarship. As noted by Isin, (2009, pp. 380-381), acts of citizenship addresses the emergence of new beginnings and identities, including the activist citizen who re-writes 
predetermined scripts and makes a difference. This political subject who emerges vis-à-vis acts can, according to Nyers (2011, p. 8), come from both "usual and unusual subjects, expected and unexpected voices, and obvious and not so obvious places, spaces, and temporalities." It is the usual, expected, and obvious that I consider in this article. I am influenced here by Castañeda (2013, p. 228), who argues the provision of medical aid to undocumented migrants in Germany disrupts exclusionary logics of citizenship, making it "a powerful form of dissent" and a fitting example of acts of citizenship. For her, these acts by physicians critically re-examine the exclusionary logic of citizenship by treating noncitizens who lack rights to healthcare as citizens who have a right to such rights. My focus on citizens also stems from my awareness of the conditions of oppression and injustice that define the lives of precarious status noncitizens. During the time of the IFHP cuts, many refugee claimants chose to not engage in (visible) acts for fear of state retribution. For example, a Program Manager approached a refugee to participate in a campaign only to be told "my family members won't come. They think the government will come after them and take away their status in Canada" (Interview with Program Manager, Toronto, 7 October 2015). According to a doctor, patients who are refugee claimants have expressly stated their fear of seeking out healthcare services, "because maybe the government will then think that they're costing the system too much and then they will not approve their refugee claim" (Interview with doctor, Toronto, 20 October 2015). Landolt and Goldring (2015, p. 854) still consider such choices as exercises of agency. In light of the above, I focus on healthcare professionals in Toronto, and their attempts to make a difference in the everyday lives of refugee claimants through healthcare provision and advocacy efforts that challenge the exclusionary nature of (non)citizenship. Prior to discussing these acts, however, it is important to situate them within the context of the IFHP.

\section{The Interim Federal Health Program (IFHP)}

Introduced through a 1957 Order-in-Council, the IFHP provides refugee claimants, protected persons, resettled refugees, and refused refugee claimants in Canada with limited, temporary healthcare coverage in the form of basic healthcare coverage, coverage for preventative and supplementary care, prescription drug coverage, certain dental procedures, limited eye care, immunization, and prenatal and obstetrical care; this is similar to what permanent residents and citizens on social assistance receive. Refugee claimants receive IFHP coverage once their claim is deemed eligible to be heard by the Immigration and Refugee Board (IRB), and it lasts until they are eligible to receive provincial healthcare coverage or can afford private health insurance. For many years the program acted as a supplementary form of coverage for those refugee claimants residing in 
the province of Ontario; prior to 1995 , refugee claimants received coverage under the Ontario Health Insurance Program (OHIP), however, eligibility rules were altered to deny coverage to this population and other temporary residents. As a result, reliance on the IFHP increased in addition to total program costs (Dhand \& Diab, 2015, pp. 357-358). By 2012, it is estimated the program covered close to 129,000 persons across Canada at a cost of over $\$ 80$ million per year (Dhand \& Diab, 2015, p. 358; Olsen et al., 2016, p. 61). Due to the increasing number of recipients, financial costs, and the broader securitized environment, as evident through the introduction of the PCISA, amendments were made to the IFHP in 2012.

On 5 April 2012, the federal government passed an Order-in-Council (P.C. 2012-433) that repealed and replaced the original 1957 Order-inCouncil that established the IFHP with a much more restrictive program, without consultation from provinces, the public, or direct stakeholders. For Sheridan and Shankardass (2015), this blatant disregard of stakeholders is a major cause of the IFHP's failure. Coming into effect on 30 June 2012, the new program restricted healthcare coverage for refugee populations, particularly refugee claimants.

The 2012 program introduced three different types of healthcare coverage: expanded healthcare coverage, basic healthcare coverage, and public health and public safety (PHPS) coverage. For refugee claimants, those from a non-designated country of origin (DCO) received basic healthcare coverage, ${ }^{3}$ which included urgent and essential medical services, limited lab and diagnostic services, and no medication or vaccinations except to prevent or treat a PHPS threat or condition. ${ }^{4}$ The most restrictive coverage - PHPS coverage - was provided to DCO claimants and failed claimants; they received no coverage for services or medications unless to prevent or treat a PHPS threat or condition, meaning that life-sustaining medications like insulin were no longer covered (CCR, 2013). For Raza, Rashid, RedwoodCampbell, Rouleau and Berger (2012, p. 728), the cuts represented a transition to "emergency treatment," which "underscores a deep change in the way in which human beings are assigned value." Here, the health and wellbeing of refugee claimants only became important if the health or safety of citizens were affected; "the refugee person in this context is no longer valued as a unique and worthy human being but is considered a 'risk factor' for others" (Raza et al., 2012, p. 728). In addition to this "insidious and deeply dehumanizing" shift (Raza et al., 2012, p. 728), the cuts increased the chances of refugee claimants opting to delay or forgo

\footnotetext{
${ }^{3}$ Introduced in 2012, Designated Countries of Origin (DCO) deemed certain countries as "safe" countries because they "do not normally produce refugees, but do respect human rights and offer state protection." People making a claim from one of these countries faced significant restrictions throughout the claim process, including limited access to the IFHP (Government of Canada, 2017). In May 2019, the federal government suspended the DCO policy.

${ }^{4}$ A PHPS threat includes tuberculosis, HIV, malaria, measles, and chicken pox. PHPS conditions include mental health conditions that may cause harm to the individual or others (Canadian Doctors for Refugee Care, et al. v. Canada, 2014, p. 25).
} 
healthcare, or be denied healthcare by professionals and frontline staff. These denials were largely a result of administrative delays, the confusion generated by the administrative complexity of determining eligibility, and the vague directions provided to healthcare providers by the federal government (Barnes, 2013, p. 6). This shaping of one's actions - delaying, denying, or forgoing care - demonstrates the effectiveness of the regulatory aspects of the IFHP.

In addition to limiting the extent of coverage and deterring the abuse of Canada's refugee determination system, an emphasis on "fairness" to Canadians and the protection of Canadian generosity was employed to justify the IFHP cuts (Fitzpatrick, 2012; Government of Canada, 2014a). As stated by then Conservative Minister of Citizenship and Immigration Jason Kenney, "Canadians take great pride in the generosity and compassion of our immigration and refugee programs. But they have no tolerance for those who abuse our generosity or take advantage of our country" (Kenney, 2012). For him, the IFHP reforms would, "stop the abuse of Canada's generous and overburdened healthcare system by bogus refugees" (Olsen et al., 2016, p. 60). This sentiment was shared by the subsequent Conservative Minister of Citizenship and Immigration Chris Alexander when he stated "we have no tolerance for those who take advantage of [our] generosity and consume welfare benefits and precious health-care resources" (Alexander, 2014). The emphasis on generosity amounts to what can be termed "Canadianness," which is "inextricably joined" to "the operation of citizenship in Canada" (Baines \& Sharma, 2002, p. 85). Ideas of Canadianness, such as being just, accepting, and tolerant, work to construct an image of the other (or non-Canadianness) as disingenuous, selfish, and threating. The agonistic relationship that emerges is one of conflict and competition, which reaffirms the privileged position and entitlements of Canadian citizenship and justifies cuts to refugee healthcare (Olsen et al., 2016, p. 59, 63; see Sharma, 2001). The IFHP cuts represent an expression of the bio-inequality founded on the prioritization of citizenship (see Willen, 2011, p. 304) and Canadianness. It can also be viewed as bolstering the foundation of the Canadian nation-state, as seen through the mobilization of an "imagined community" of Canadians, so as to enact the state's duty to protect the virtuousness of citizenship and the security of citizens and social programs (see Baines \& Sharma, 2002). In this regard, the targeting of refugee claimants arises as a result of the very nature of citizenship and the nation-state. The IFHP allows us to witness not only the nature of power and citizenship, but how the content and extent of citizenship shifts over time. Furthermore, it illustrates not so much the construction of irregularity as its reconstruction.

In response to the 2012 cuts, a Charter challenge was launched against the federal government by the Canadian Doctors for Refugee Care (CDRC), the Canadian Association of Refugee Lawyers (CARL), Justice for Children and Youth (JFCY), and two refugee claimants, Daniel Garcia 
Rodriguez and Hanif Ayubi. They requested a judicial review of the federal government's decision to reduce coverage, claiming the cuts were inconsistent with Canada's international obligations to refugees and in violation of Section 7 (the right to life and security of the person), Section 12 (cruel and unusual treatment), and Section 15 (discrimination) of the Canadian Charter of Rights and Freedoms (CARL, 2013). On 4 July 2014, the Court ruled the cuts were in violation of Sections 12 and 15 of the Charter and ordered the Conservative government to draft a new Chartercompliant policy within a four-month timeline. The government appealed the ruling, reflecting their support of this policy, and requested to suspend the decision until the appeal was heard, which the Federal Court of Appeal denied (CARL, 2014). The government introduced the "temporary IFHP" on 4 November 2014 while appealing the Court decision.

The temporary IFHP restored benefits to pregnant women and children, and covered medical, diagnostics, hospital services, and medications for PHPS threats or conditions for all refugee claimants regardless of country of origin (Government of Canada, 2014b). However, this victory was shortlived because the new revisions to the program added more confusion to an already complex program through the introduction of six types of healthcare coverage (with refugee claimants receiving "type three" coverage) (see Government of Canada, 2014c). A doctor argues that this temporary program forced professionals to navigate a "complex matrix of impenetrable and incomprehensible degrees of coverage," leading many to "just throw up their hands and give up" (Interview with Doctor, Toronto, 10 November 2015). The confusion and resulting withdrawal of physicians was "one unexpected impact" of the IFHP changes (Barnes, 2013, p. 6), highlighting the indeterminacy of access to healthcare and the expansion of disentitlement that defined this era.

Below, I detail how the IFHP - including its complexity and discourses of noncitizenship - came to shape encounters between refugee claimants and healthcare professionals within Toronto's healthcare setting. The everyday healthcare places that constitute this setting are sites where (non)citizenship is (re)negotiated and where the irregularity of noncitizenship is (re)constructed.

\section{(Re)Constructing Irregularity in Toronto's Everyday Healthcare Places}

In Toronto's everyday healthcare places, the (re)construction of irregularity is evident when refugee claimants are "made ineligible for care" (Interview with Policy Analyst, Toronto, 21 October 2015). Making one ineligible for care, and hence inscribing a status that informs this ineligibility, emerges through encounters between healthcare professionals (including frontline staff) and refugee claimants with IFHP coverage. Shaping the encounter are 
the healthcare professionals' imaginations of refugee claimants, limited understandings of the IFHP (Barnes, 2013, p. 6; Interview with doctor, Toronto, 20 November 2015), assessments of the moral worth of refugee claimants, and personal evaluations of Canada's socioeconomic situation (Vanthuyne et al., 2013; see Villegas 2015a, p. 233) all of which may combine to threaten the health and well-being of precarious status noncitizens.

Prior to the 2012 changes, all IFHP recipients received the same type of coverage, which not only allowed doctors to more easily navigate the program, but also made the program more acceptable and normal. As stated by a doctor:

As long as someone had a valid IFH certificate, you didn't have to know if they were government assisted, or privately sponsored, or a claimant, or they were from this country, or they had their hearing, or they're filing a federal court review. That became irrelevant. It became just like having an OHIP card in many ways. (Interview with Doctor, Toronto, 19 October 2015)

Here, the acceptability of the program - based upon its likeness to OHIP had an effect on how recipients were encountered. The program's similarity to OHIP normalized and rendered more acceptable the presence of IFHP recipients, thereby according a regularized social positioning within the healthcare setting. However, the IFHP is not OHIP; it is visibly different, and has separate bureaucratic regulations, payment delays, pre-approval processes, and lower financial compensation (McKeary \& Newbold, 2010; Olsen et al., 2016). These fundamental differences meant that access to healthcare services was not always guaranteed. According to a social worker, "I remember having clients in 2010 who would say 'I tried to go to the doctor and they didn't understand what IFH was' [...], and I remember having to explain it to a secretary, like a medical secretary" (Interview with Social Worker, Toronto, 26 November 2015). Lack of familiarity with the program may not have been the only issue. One doctor questions whether healthcare professionals "have chosen on purpose to not register [to provide IFHP services]" (Interview with Doctor, Toronto, 20 October 2015). They explain:

We came across this with a dermatology clinic that I sent a patient to - that I send most of my other patients to who have OHIP - and they refused to see him, and they said "We're not an IFH provider", and apparently that's allowed. That they can just say that they don't provide IFH. That they don't serve this population. (Interview with Doctor, Toronto, 20 October 2015)

This quote illustrates what Raza et al. (2012) argue is the increasing devaluation of the lives of refugee claimants. In this regard, there is both an ignorance of this program, as well as an unwillingness to learn about it and provide primary care services to those with IFHP coverage. Accompanying 
such forms of devaluation was not only the (re)affirmation of the value and validity of OHIP and OHIP recipients - a signifier of belonging and membership within the nation-state - but the negative imaginations of refugee claimants.

As argued by Isin (2002, p. 34), "dominant groups often develop strategies and technologies to adjure the dominated to recognize that they lack virtue." While the IFHP revision is an example of this, Isin reminds us to also be aware of the qualities and stereotypes attributed to dominated groups, which typically are the worst attributes of the dominant group. These attributes work to legitimize unequal treatment and form irregularized identities. Some forms of unequal treatment and discrimination within healthcare settings include religious or cultural insensitivity, unfriendly behaviour, "racial slurs, stereotyping, and receipt of inferior care" (Pollock, Newbold, Lafrenière \& Edge, 2012, p. 63). As a refugee claimant explains, "I can feel the discrimination when I pull out my papers. I don't have OHIP. The receptionist's face will take on a look of disdain. I get worse treatment than the Canadians who have the right card" (Campbell, Klei, Hodges, Fisman \& Kitto, 2014, p. 172). Other examples include a refugee claimant with IFHP coverage who had contrasting experiences with two doctors within a Toronto walk-in clinic (Interview with Refugee Claimant, Toronto, 11 March 2017), and "incidence[s] of hospitals trying to convince people that it's not an emergency in order to get them [un(der)insured people] to go away" (Interview with Program Manager, Toronto, 8 October 2015). Pregnant refugee claimants, and other un(der)insured pregnant precarious status noncitizens, were particularly prone to discrimination, disproportionate health risks, and inconsistent access to healthcare.

Labelled as "medical tourists" who deliver "anchor babies" (Villegas, 2010, cited in Vanthuyne et al., 2013, p. 81), pregnant refugee claimants embody the discourses of greedy and threatening others, leading Tyler (2013, p. 217) to argue that their bodies come to be constructed as "corporeal border zones" to manage "the undesirable reproduction of noncitizens." The targeting of noncitizen bodies occurred irrespective of IFHP coverage. Consider for example when a pregnant refugee claimant from Mexico was forced to sign a waiver by a hospital administrator - as per hospital policy - rendering her responsible for hospital fees should her IFHP coverage change, or when another pregnant refugee claimant was told by her obstetrician that she would need to pay $\$ 1,500$ or be denied further services, even though both women had full IFHP coverage as a result of making refugee claims prior to 2012 (Marwah, 2014, p. 10; interview with doctor, 19 October 2015). These cases, along with many others, highlight how increased risks of targeting, discrimination, and denied access to services is a result of non-state actors who may come to employ a more exclusionary construction of noncitizenship beyond that which is prescribed by the state (Bloom 2015, p. 895). According to a midwife, the lack of 
OHIP documentation played a key role in targeting and rendering pregnant women irregular:

I feel like there is that kind of prejudice where somebody assumes like, oh she doesn't have OHIP, she's not going to be able to pay, she's here illegally, or without status. So, I think that's a lot of social barriers [and] racism that people encounter in these situations. (Interview with Midwife, Toronto, 22 January 2016)

The utilization of (non)citizenship discourses can render the presence and healthcare claims of refugee claimants as out of place regardless of the legally authorized status of refugee claimants and the rights accorded to them. I take these cases as illustrations of how the (re)construction of irregularity can be imagined and the manner in which noncitizenship is an "emergent condition" (Hepworth, 2014).

Although this article focuses on denied or restricted access to healthcare services, not all refugee claimants with IFHP coverage faced such barriers. As noted by one refugee claimant, "when my answer hadn't arrived yet, everything was good. I was getting medical attention from the doctors without paying anything from my pocket. So, the government was covering that $[\ldots]$ so it was really helpful" (Interview with refugee claimant, Toronto, 18 October 2015). In this regard, while the IFHP is foundational to the irregularity of refugee claimants, it is simultaneously a means to ameliorate irregularity and its affects (of denied access); without access to the limited program, refugee claimants would face significantly more barriers to healthcare. Irregularity is not fixed. Rather, it is inconsistently and contingently (re)constructed. As one lawyer notes, while patients may be denied "immediate access," a process of "going back and forth, back and forth, [having] several conversations" may eventually lead to accessing the required service (Interview with lawyer, Toronto, 11 November 2015). The important point here is that the consequences of such inconsistencies, including those discussed in the cases above, are different and perhaps more consequential for those with an irregularized status. Rather than approaching irregularity and noncitizenship as either/or scenarios, it is in fact much more complex.

\section{Resisting Irregularity in Toronto's Healthcare Setting}

The complexity of irregularity lies not only in its (re)production but also its confrontation. In the IFHP case, an impressive counter-mobilization emerged that not only defeated the government before the courts, but also served to publicize and sensitize Canadians to the experiences, needs, and rights of refugee claimants and prompt Canadians to critically question the exclusionary nature of their healthcare system. This was complemented by the everyday acts of healthcare professionals who played a key role in 
challenging the boundaries upheld by citizenship by providing medical aid; for Castañeda $(2013$, p. 229), this "has the ability to disrupt the scaling of citizenship" and undermine its exclusionary organizing principles. Important actors here include doctors from Toronto's Inner City Health Associates (ICHA) who offer primary care and psychiatric services (as well the costs of x-rays, ultrasounds, and potentially blood work and medications) to residents of drop-in centres, homeless shelters, and refugee shelters (Interview with doctor, Toronto, 20 October 2015). Also important are the services provided at Crossroads Refugee Clinic which is Toronto's first hospital-based refugee health clinic, Toronto's community health centres, and uninsured clinics such as the Canadian Centre for Refugee \& Immigrant Healthcare (CCRIH) and the Scarborough Women Assessments and Needs (SWAN) Clinic, where inter-disciplinary teams of healthcare professionals offer free primary, paediatric, dental, and chiropractic services regardless of status (CCRIH, n.d.). I view the act of healthcare provision as having both momentary and momentous political effects.

The direct provision of care can be understood as an enactment of "momentary" politics (Johnson, 2012, p. 115), in that it may not overtly challenge systemic practices but does establish noncitizens as rights bearing subjects. Furthermore, in these momentary acts, healthcare providers documented the impacts of the IFHP revisions through the Refugee Health Outcome Monitoring and Evaluation System (Refugee HOMES) tool, "a simple online survey that is completed by health providers when they care for refugees" (Barnes, 2013, p. 3). The knowledge generated through this tool informed publications, pamphlets, demonstrations, campaigns, letters, media statements, and National Days of Action, and was used as evidence in the Court challenge. It can be argued that the Liberal party came to echo the issues raised in the collection of this data in their political platform, as noted by their desire to fully re-instate the IFHP (Liberal Party of Canada, 2015 , p. 65). In this sense, the effects of service provision impact more than the confines of the everyday and individual lives. There is a scalar aspect of acts, in that there is an important intimate connection between momentary and momentous resistance to the systemic features of irregularization.

However, the provision of the above services was and continues to be patchy. For example, ICHA does not provide services everywhere and oftentimes refugee claimants only find their services by chance. As noted by one refugee claimant:

Because I was from [Seaton House], first started, they provide me service from a family doctor. They are giving me service until now. But if I directly came here [to my current refugee shelter], then it was a problem for me. There is no service. I have to pay from my pocket. Money I have not, then it's extremely a problem for me. (Interview with Refugee Claimant, Toronto, 11 March 2016)

A social worker offers a similar account of serendipitous healthcare service discovery in that as a result of residing within a specific shelter, access to a 
family physician may be provided (Interview with Social Worker, Toronto, 26 November 2015). Furthermore, not all medications are covered. According to a refugee claimant, after informing the doctor of his prescribed diabetes medication he received in his country of origin, the doctor at the shelter responded, "we are paying, and that this is very costly, we can't provide these pills to you, we will give other pills that will control your diabetes but slowly" (Interview with Refugee Claimant, Toronto, 11 March 2016). He follows this by stating "at my home, I was taking only one pill in the morning for diabetes, but here, two in the morning, two in the evening. Four pills I am taking for diabetes. That is a problem" (ibid.). While providing healthcare to refugee claimants within the spaces they inhabit is an act that aims to break down barriers, we continue to witness the perpetuation of what Villegas (2013, p. 221) argues is the "insecure and negotiated quality of access to health care" among Canada's precarious status noncitizens.

This insecure access is also reflected in the unreliability of uninsured clinics with regards to knowing "where they are and how to access them and what services they provide and when they provide them, because $[\ldots]$ they are not open every day of the week" (Interview with City Official, Toronto, 6 October 2015). The difficulty in finding these healthcare places for underinsured populations like IFHP recipients is an effect of the silence that surrounds them. As one doctor states, the provision of healthcare is "a balance between wanting people to know they can seek services versus not declaring that we are providing services to people who are potentially nonstatus" (Interview with doctor, Toronto, 20 October 2015). Drawing upon Nyers' (2010, p. 141) critique of the Sanctuary City, the provision of healthcare services to irregularized populations arguably inadvertently "reproduce[s] the logic of silence, [and] subterfuge" that characterizes their daily lives while simultaneously aiming to avoid the gaze and "sovereign retakings" of the state (Nyers, 2003, pp. 1086-1087). The provision of healthcare services to refugee claimants is laudable, and the degree to which these actors affect the everyday lives of refugee claimants is remarkable. However, their acts can produce unintended outcomes.

In their attempts to humanize refugee claimants, healthcare professionals and allies utilized familiar paternalistic discourses of voicelessness and powerlessness, which are themselves key indicators of "refugeeness" (Malkki, 1996, p. 385). According to one doctor:

One of the things we can easily be accused of is paternalism, speaking on behalf of people, but [...] they couldn't. They were terrified. They didn't want to expose themselves to the state, and so, because they couldn't speak, we had to. There was [...] this leading American doctor who said that doctors had a duty to use their voices loudly and strongly to intervene on behalf - to intervene not only for justice and healthcare, but for justice in general which is affecting patients' health, [...] and that's exactly what we were doing the whole time. (Interview with Doctor, Toronto, 10 November 2016, emphasis added) 
This duty to protect may perpetuate unequal power relations, speaking to how the places and roles of citizens and noncitizens is a central dilemma of migrant politics (Castañeda, 2013, p. 233; see Nyers, 2003). Beatson (2016, p. 130) argues the victim frame employed by physicians and allies during the IFHP protests emphasized passivity, along with charity (over obligation), which avoids any serious attempt "to elevate the status of refugee claimants in Canadian society on a more fundamental and permanent level." The contradictions and complexities emerging from acts are an indication of how they risk reinstating exclusionary configurations. In addition to such depoliticized framings of refugee claimants, the persistent call for the reinstatement of the IFHP among healthcare professionals and refugee advocates (CDRC, n.d.) - as a way to rectify the negative impact of the cuts - may in fact perpetuate the irregularity of refugee claimants. As noted in this article, the program is inherently irregularizing as a result of being administered within a context that prioritizes national citizenship, the rights of citizens, and provincial or territorial healthcare coverage.

\section{Conclusion}

The confusion and barriers created through the IFHP revisions came to an end in April 2016 when the program was fully restored to its pre-2012 levels under the newly elected federal Liberal government; it was further expanded in April 2017 to refugees awaiting resettlement to Canada. However, concerns continue to be raised about the healthcare barriers faced by refugee claimants and other un(der)insured and nonstatus persons (Caulford \& Rahunathan, 2017; Chen, Gruben \& Liew, 2018; Wright, 2018), alerting us to how this program perpetuates health inequality and contributes to the (re)irregularization of refugee claimants. In this article, I draw on critical citizenship and migration scholarship (Baines \& Sharma, 2002; Castañeda, 2013; Hepworth, 2014; Isin, 2002), to highlight how the irregularity of refugee claimants was (re)constructed during the time of revisions (2012-2016) in ways that led to denied access to healthcare coverage and services. I also reveal how healthcare providers resist irregularity - as acts of citizenship - and the consequences of such forms of resistance and struggle. In this regard, I emphasize how irregularity entails regulatory and resistive elements, which accentuates the messiness that defines (non)citizenship and the experiences of precarious status noncitizens. Through the lens of irregularity, this paper draws further attention to how the healthcare rights and entitlements of refugee claimants within Canada are circumvented by way of (re)constructing a non-juridical status at both national and local scales. 
The rights and overall wellbeing of refugee claimants are also challenged outside of the healthcare sector. Refugee claimants face barriers to affordable, long-term shelter (Kissoon, 2013; Rider, 2018), and female refugee claimants navigate a system that often does not recognize their genuine fear of domestic abuse (Bhuyan, Vargas \& Pintin-Perez, 2016). Furthermore, Canada continues to differentiate asylum claims based upon country of origin, while Canadian citizenship is increasingly being rendered a "conditional privilege," leading to "citizenship stripping" and de facto statelessness (Stasiulis, 2017, pp. 2-3). Coming to terms with irregularity within this context will allow scholars and activists to critically confront the naturalness with which the virtuousness of citizenship is portrayed, and the barriers to justice and equity that it upholds.

\section{References}

Alexander, C. (2014) Speaking notes for Chris Alexander, Canada's Citizenship and Immigration Minster at the News Conference Regarding Canada's Asylum System. Retrieved from https://www.canada.ca/en/news/archive/2014/03/speaking-notes-chrisalexander-canada-citizenship-immigration-minister-news-conference-regarding-canadaasylum-system.html

Atak, I., Hudson, G., \& Nakache, D. (2017). "Making Canada's refugee system faster and fairer": Reviewing the stated goals and unintended consequences of the 2012 reform. CARFMS/ACERMF Working Paper No: 2017/3. Retrieved from http://carfms.org/wpcontent/uploads/2017/05/CARFMS-WPS-No11-Idil-Atak.pdf

Baines, D., \& Sharma, N. (2002). Migrant workers as non-citizens: The case against citizenship as a social policy concept. Studies in Political Economy, 69, 75-107.

Barnes, S. (2013). The real cost of cutting the Interim Federal Health Program. Wellesley Institute Policy Paper. Toronto: Wellesley Institute. Retrieved from https://www.researchgate.net/profile/Steve_Barnes3/publication/261398823_The_Real Cost_Of_Cutting_The_Interim_Federal_Health_Program/links/0a85e5342a $\overline{6} 7 \mathrm{e} 5 \overline{\mathrm{d}} 8 \mathrm{e} 400 \overline{0} 0$ 000/The-Real-Cost-Of-Cutting-The-Interim-Federal-Health-Program.pdf

Beatson, J. (2016). The stories we tell about refugee claimants: Contested frames of the healthcare access question in Canada. Refuge, 32(3), 125-134.

Bhuyan, R. (2012). Negotiating citizenship on the frontlines: How the devolution of Canadian immigration policy shapes service delivery to women fleeing abuse. Law \& Policy, 34(2), 211-236.

Bhuyan, R., Vargas, A., \& Pintin-Perez, M. (2016). Fleeing domestic abuse from a "safe" country?: Refugee determination for Mexican asylum-seekers in Canada. Refuge, 32(3), 95-107

Bloom, T. (2015). The business of noncitizenship. Citizenship Studies, 19(8), 892-906.

Campbell, R., Klei, A. G., Hodges. B., Fisman, D., \& Kitto, S. (2014). A comparison of health access between permanent residents, undocumented immigrants and refugee claimants in Toronto, Canada. Journal of Immigrant \& Minority Health, 16, 165-176.

CARL (Canadian Association of Refugee Lawyers). (2013). Health care for refugees. Retrieved from http://www.carl-acaadr.ca/our-work/issues/IFHP

CARL (Canadian Association of Refugee Lawyers). (2014). Conservative government still undermining refugee health care: Goes behind closed doors to retroactively end IFH program. Retrieved from http://www.carlacaadr.ca/articles/govtunderminingrefugeehealthcare

CCRIH (Canadian Centre for Refugee \& Immigrant Health Care). (n.d.). Retrieved from https://www.healthequity.ca/swan-clinic/ 
CCR (Canadian Council for Refugees). (2013). Basic overview of IFH coverage. Retrieved from http://ccrweb.ca/sites/ccrweb.ca/files/ifh-coverage-overview.pdf

CDRC (Canadian Doctors for Refugee Care). (n.d.). Retrieved from http://www.doctorsforrefugeecare.ca

Canadian Doctors for Refugee Care et al. v. Canada (2014).

The Canadian Association of Refugee Lawyers, Daniel Garcia Rodriques, Hanif Ayubi and Justice for Children and Youth v. Attorney General of Canada and Minister of Citizenship and Immigration, FC 651 (2014).

Castañeda, H. (2013). Medical aid as protest: acts of citizenship for unauthorized im/migrants and refugees. Citizenship Studies, 17(2), 227-240.

Caulford, P., \& Rahunathan, S. (2017). Children and youth new to Canada: Medical care denied - A growing health poverty. Scarborough, ON: Canadian Centre for Refugee and Immigrant Health Care.

Chen, Y.Y., Gruben, V., \& Liew, J. (2018). "A legacy of confusion": An exploratory study of service provision under the reinstated Interim Federal Health Program. Refuge, 34(2), 94102.

Dhand, R., \& Diab, R. (2015). Canada's refugee health law and policy from a comparative, constitutional, and human rights perspective. Canadian Journal of Comparative \& Contemporary Law, 1, 351-406.

Fitzpatrick, M. (2012, April 25). Refugee health benefits scaled back by Tories. CBC News. Retrieved from http://www.cbc.ca/news/politics/refugee-health-benefits-scaled-back-bytories-1.1164074

Goldring, L., Berinstein, C., \& Bernhard, J. (2009). Institutionalizing precarious migratory status in Canada. Citizenship Studies, 13(3), 239-265.

Government of Canada. (2014a). Speaking notes for Chris Alexander, Canada's Citizenship and Immigration Minister at the News Conference Regarding Canada's Asylum System. Retrieved from https://www.canada.ca/en/news/archive/2014/03/speaking-notes-chrisalexander-canada-citizenship-immigration-minister-news-conference-regarding-canadaasylum-system.html

Government of Canada. (2014b). Notice - Temporary measures for the Interim Federal Health Program. Retrieved from https://www.canada.ca/en/immigration-refugeescitizenship/news/notices/notice-temporary-measures-interim-federal-healthprogram.html

Government of Canada. (2014c). Interim federal health program policy. Retrieved from http://www.cic.gc.ca/english/department/laws-policy/ifhp.asp

Government of Canada. (2017). Designated countries of origin. Retrieved from http://www.cic.gc.ca/english/refugees/reform-safe.asp

Hepworth, K. (2014). Encounters with the clandestino/a and the nomad: The emplaced and embodied constitution of non-citizenship. Citizenship Studies, 18(1), 1-14.

Huot, S., Bobadilla, A., Bailliard, A., \& Rudman D. (2015). Constructing undesirables: A critical discourse analysis of 'othering' within the Protecting Canada's Immigration System Act. International Migration, 54(2), 131-143.

Isin E. (2002). Being political: Genealogies of citizenship. Minneapolis, MN: University of Minnesota Press.

Isin, E. (2008). Theorizing acts of citizenship. In E. Isin \& G. Neilson (Eds.), Acts of citizenship (pp. 15-43). New York: Zed Books.

Isin. E. (2009). Citizenship in flux: The figure of the activist citizen. Subjectivity, 29, 367-388.

Isin, E., \& Neilson, G. (2008). Introduction. In E. Isin \& G. Neilson (Eds.), Acts of Citizenship (pp. 1-12). New York: Zed Books.

Jackson, S. (2018). Politicizing the white coat: Physician activism and asylum seeker healthcare in Canada, Germany and England (Unpublished doctoral dissertation). McMaster University, Hamilton, ON.

Johnson H. (2012). Moments of solidarity, migrant activism and (non)citizens at global borders: Political agency at Tanzanian refugee camps, Australian detention centres, and European borders. In P. Nyers \& K. Rygiel (Eds.), Citizenship, migrant activism, and the politics of movement (pp. 109-128). New York: Routledge.

Studies in Social Justice, Volume 13, Issue 2, 201-220, 2019 
Johnson, H. (2014). Borders, asylum and global non-citizenship: The other side of the fence. Cambridge: Cambridge University Press.

Kenney, J. (2012) Speaking notes for The Honourable Jason Kenney, P.C., M.P Minister of Citizenship, Immigration and Multiculturalism. Retrieved from https://www.canada.ca/en/immigration-refugees-citizenship/news/archives/speeches2012/jason-kenney-minister-2012-02-16.html

Kissoon, P. (2013). Precarious immigration status and precarious housing pathways: Refugee claimant homelessness in Toronto and Vancouver. In L. Goldring \& P. Landolt (Eds.), Producing and negotiating non-citizenship: Precarious legal status in Canada (pp. 195220). Toronto, ON: University of Toronto Press.

Landolt, P., \& Goldring, L. (2015). Assembling noncitizenship through the work of conditionality. Citizenship Studies, 19(8), 853-869.

Liberal Party of Canada. (2015). Real change: A new plan for a strong middle class. Retrieved from https://www.liberal.ca/wp-content/uploads/2015/10/New-plan-for-a-strong-middleclass.pdf

Malkki, L. (1996). Speechless emissaries: Refugees, humanitarianism, and dehistoricization. Cultural Anthropology, 11(3), 377-404.

Marwah, S. (2014). Refugee health care cuts in Canada: System level costs, risks and responses. Wellesley Institute Policy Paper. Toronto: Wellesley Institute. Retrieved from https://www.wellesleyinstitute.com/publications/refugee-health-care-cuts-in-canadasystem-level-costs-risks-and-responses/

McKeary, M., \& Newbold, B. (2010). Barriers to care: The challenges for Canadian refugees and their health care providers. Journal of Refugee Studies, 23(4), 523-545.

McNevin, A. (2011). Contesting citizenship: Irregular migrants and new frontiers of the political. New York: Columbia University Press.

Müller, T. (2016). Acts of citizenship as a politics of resistance? Reflections on realizing concrete rights within the Israeli asylum regime. Citizenship Studies, 20(1), 50-66.

Ní Mhurchú, A. (2016). Unfamiliar acts of citizenship: Enacting citizenship in vernacular music and language from the space of marginalised intergenerational migration. Citizenship Studies, 20(2), 156-172.

Nyers, P. (2003). Abject cosmopolitanism: The politics of protection in the anti-deportation movement. Third World Quarterly, 24(6), 1069-1093.

Nyers, P. (2006). Taking rights, mediating wrongs: Disagreements over the political agency of non-status refugees. In J. Huysmans, A. Dobson \& R. Prokhovnik (Eds.), The politics of protection: Sites of insecurity and political agency (pp. 48-67). New York: Routledge.

Nyers, P. (2010). No one is illegal between city and nation. Studies in Social Justice, 4(2), 127-143.

Nyers, P. (2011). Alien inequality. Issues in Legal Scholarship, 9(1), 1-13.

Olsen, C., El-Bialy, R., Mckelvie, M., Rauman, P., \& Brunger, F. (2016). "Other" troubles: Deconstructing perceptions and changing responses to refugees in Canada. Journal of Immigrant \& Minority Health, 18, 58-66.

Pollock, G., Newbold, B., Lafrenière, G., \& Edge, S. (2012). Discrimination in the doctor's office: Immigrants and refugee experiences. Critical Social Work, 13(2), 60-79.

Raza, D., Rashid, M., Redwood-Campbell, L., Rouleau, K., \& Berger, P. (2012). A moral duty: Why Canada's cuts to refugee health must be reversed. Canadian Family Physician, 58, 728-729.

Rider, D. (2018, May 23). Facing refugee influx, Toronto triggers emergency shelter plan. Toronto Star. Retrieved from https://www.thestar.com/news/canada/2018/05/23/facingrefugee-influx-torontotriggers-emergency-shelter-plan.html

Rygiel, K. (2011). Bordering solidarities: Migrant activism and the politics of movement and camps at Calais. Citizenship Studies, 15(1), 1-19.

Sharma, N. (2001). On being not Canadian: The social organization of 'migrant workers' in Canada. Canadian Review of Sociology \& Anthropology, 38(4), 415-439.

Sheridan, P., \& Shankardass, K. (2015). The 2012 cuts to refugee health coverage in Canada: The anatomy of a social policy failure. Canadian Journal of Political Science, 48(4), 905-931. 
Squire, V. (2011). The contested politics of mobility: Politicizing mobility, mobilizing politics. In V. Squire (Ed.), The contested politics of mobility: Borderzones and irregularity ( $\mathrm{pp}$. 1-26). New York: Routledge

Stasiulis, D. (2017). The extraordinary statelessness of Deepan Budlakoti: The erosion of Canadian citizenship through citizenship deprivation. Studies in Social Justice, 11(1), 126.

Tyler, I. (2013). Naked protest: The maternal politics of citizenship and revolt. Citizenship Studies, 17(2), 211-226.

Turner, B. (1997). Citizenship studies: A general theory. Citizenship Studies, 1(1), 5-18.

Vanthuyne, K., Meloni, F., Ruiz-Casares, M., Rousseau, C., \& Ricard-Guay, A. (2013). Health workers' perceptions of access to care for children and pregnant women with precarious immigration status: Health as a right or a privilege? Social Science \& Medicine, 93, 7885.

Villegas, P. (2013). Negotiating the boundaries of membership: Health care providers, access to social goods, and immigration status. In L. Goldring \& P. Landolt (Eds.), Producing and negotiating non-citizenship: Precarious legal status in Canada (pp. 221-237). Toronto, ON: University of Toronto Press.

Villegas, P. (2015a). Fishing for precarious status migrants: Surveillant assemblages of migrant illegalization in Toronto, Canada. Journal of Law \& Society, 42(2), 230-252.

Villegas, P. (2015b). Moments of humiliation, intimidation ad implied 'illegality': Encounters with immigration officials at the border and the performance of sovereignty. Journal of Ethnic \& Migration Studies, 41(14), 2357-2375.

Willen, S. (2011). Do "illegal" im/migrants have a right to health? Engaging ethical theory as social practice at a Tel Aviv open clinic. Medical Anthropology Quarterly, 25(3), 303330.

Wright, T. (2018, August 15). Canada violated rights of irregular migrant by denying her essential health-care: UN Human Rights Committee. The Globe and Mail. Retrieved from https://www.theglobeandmail.com/canada/article-canada-violated-rights-ofirregular-migrant-by-denying-access-to/ 